\title{
The effects of an IT-related curriculum based on hybrid-style problem- based learning on career decision-making self-efficacy of women's University students in Korea
}

\author{
Hee Yeong Kim \\ June-Suh Cho \\ Hankuk University of Foreign Studies, Seoul, Korea
}

\begin{abstract}
Keywords
Problem-Based Learning; Career Decision-Making Self-Efficacy; Women's University Students; Information Technology Related Curriculum
\end{abstract}

\begin{abstract}
The unemployment of university students has been emerging as a significant social issue in South Korea, making it more necessary for students to have the attitude and confidence needed to explore their future options. This study examines whether women's university students are actively committed to making decisions and having confidence in their career choices when applying Problem-Based Learning (PBL) to the Information Technology Curriculum. For the design of this study, two women's universities were selected: group A consisted of 'A University' students given hybrid-style PBL and group B consisted of 'B University' students given traditional lectures and practices. A Nonequivalent Control Group Pretest-Posttest Design was used to analyze the experimental group and the control group with pretest questionnaires at the beginning of a semester and posttest questionnaires at the end of the semester.

The study results confirmed that PBL improves the Career Decision Making Self-Efficacy of women's university students in giving them confidence in their ability to collect career information, awareness of career objectives, belief in planning and doing, and self-assessment for choosing suitable careers for themselves. This study suggests that more problem-based learning curricula need to apply PBL to future ITrelated curricula to help students make their own career decisions.
\end{abstract}

Corresponding author: June-Suh Cho

Email addresses for corresponding author: jscho@hufs.ac.kr

First submission received: $6^{\text {th }}$ November 2017

Revised submission received: $2^{\text {th }}$ January 2018

Accepted: 25 $5^{\text {th }}$ March 2018

Acknowledgement

This study was supported by Hankuk University of Foreign Studies Research Fund of 2018

Introduction

The problem of university student unemployment is becoming a social issue in Korea. The Statistical Yearbook (the Korean Educational Development Institute) shows that the employment rate of university students has declined sharply since 2010, as shown in Table 1, and has not recovered to date in 2017. The issue that university students aged 20-24 years old worried about is career relating to occupations ${ }^{1}$. The area relating to 'career' represents the highest $30 \%$ in the student consultation results of the Student Counseling Center of Dong-A University in Korea for the period of 2008 to 2010.

To the problem of youth unemployment, the Korean government is implementing various policies. Universities have also been developing and implementing a variety of programs to increase the employment rate of graduates. However, the companies that hope to employ university graduates are in a dilemma, because it is not easy for them to find good workers. Most graduates are not ready to work immediately in the field when employed. They need new education and training to achieve productivity

1 Statistics Korea, http:/ / www.kostat.go.kr, accessed 10 January 2016. 
in industry. The companies have no money and time to spend for new employees and tend to strongly favor the experienced ${ }^{2}$.

$<$ Table 1> Employment rate of University graduates [Unit: \%]

\begin{tabular}{|l|l|l|l|l|l|l|l|l|l|l|}
\hline & 2005 & 2006 & 2007 & 2008 & 2009 & 2010 & 2011 & 2012 & 2013 & 2014 \\
\hline $\begin{array}{l}\text { *Entire institutions of } \\
\text { higher education }\end{array}$ & 74.1 & 75.4 & 75.8 & 76.7 & 76.4 & 55 & 58.6 & 59.5 & 59.3 & 58.6 \\
\hline Technical Universities & 83.7 & 84.2 & 85.2 & 85.6 & 86.5 & 55.6 & 60.7 & 60.8 & 61.2 & 61.4 \\
\hline Universities & 65 & 67.3 & 68 & 68.9 & 68.2 & 51.9 & 54.5 & 56.2 & 55.6 & 54.8 \\
\hline
\end{tabular}

* includes technical universities, universities, graduate schools, etc.

On the other hand, job seekers find it is not easy to decide what companies would be good to join. University graduates often quit their jobs, even when employment did not come to them easily, without working long enough. One of the biggest reasons is job mismatching, which is very serious in Korea. There are many factors to be matched, such as region, technology, school level, age, and wage (Kim and Kim, 2015). The job mismatch of a youth's beginning career can have a negative effect throughout his or her lifetime, and avoiding it is very important (Liu and Chen, 2014). Students during their school days have to investigate job and company information deeply in order to avoid job mismatching, and some subjects have to help them do so. Learning how to choose a job that suits them and how to improve their decision-making ability is an essential process for prospective university graduates; and it will be of great help if they can acquire this ability through the university curriculum.

The employability of university students will be further increased if they explore careers or prepare themselves to be equipped with the necessary knowledge, attitudes, and skills to make the right career decisions. Applying Problem-Based Learning (hereinafter referred to as PBL) to class operation is an ongoing effort. PBL is an educational approach that enables learners to find and learn by themselves by dealing with problems derived from lives or jobs in unstructured form. As the problems presented in the study are similar to the situations that learners will experience, the learners will be more interested in facing such challenges in learning. The role of teachers in PBL is not to simply inject or transfer knowledge, but to guide and help the learners solve problems by themselves. In South Korea, where employment is emerging as a significant social issue, efforts to identify and use the problems to be applied to classes in conjunction with employment can be of help to a student's career decisions. That is, when conducting a class as a process for students to solve problems, studying what effects PBL has on career choice and decisions of students, especially women's university students, is a meaningful effort to find a solution for youth unemployment. Determination would help solve the mismatching problems of the students.

The purpose of this study examines what effects applying PBL to IT-related courses will have on the career decision-making efficacy of women's university students. The experiments applying PBL to them are necessary for more effective use of PBL in the future; the implications to be derived from the results of the studies should provide a vital basis for the development of future curricula.

\section{Theoretical Background}

\section{Career Decision-Making Self-Efficacy (CDMSE)}

Career decision making, and career preparation are affected by cognitive variables, such as the self-efficacy of each person (Lent et al., 2002). Self-efficacy is a belief in one's ability to organize and carry out a series of acts required to conduct a certain task (Bandura, 1977); career decision-making self-efficacy is a concept related to how much confidence a student has in making a career decision for employment (Vinokur et al., 1991). Hackett \& Betz (1981) defined career decision-making self-efficacy as an individual's belief in his/her ability to successfully conduct tasks related to career decision-making.

The career decision-making self-efficacy exerts an important influence on the choice of occupation or career path, effective decision-making, and continual execution of plans, and can be explained as an important variable in decisions about desired achievements, career decision-making, and success in career (Luzzo, 1996). Career decision-making self-efficacy was shown to develop social-cognitive skills needed

${ }^{2}$ Asia News Agency, Recruiting managers favor the experienced, 2014.12.2. 
for jobs at employment preparation time and to affect the possibility of employment (McArdle et al., 2007). It was confirmed that career decision-making self-efficacy is an important variable in explaining the career choice process (Restbog et al., 2010).; many studies on career decision-making self-efficacy have shown that students tend to actively do what is needed to achieve higher self-efficacy concerning career decisionmaking (Betz et al., 1996; Taylor \& Betz, 1983).

Problem-Based Learning (PBL)

PBL is a pedagogical method designed to teach students how to gain knowledge and experience by seeking solutions and finding answers by themselves through practical applications, as opposed to the educational method of simply delivering knowledge to students through lectures by professors. PBL can thus be said to be a learning method in which learners think about how to solve problems and prepare solutions in collaboration with each other by forming small groups with fellow students and conducting collaborative learning (Barrows, 1996). According to studies from 1970 to 1992 analyzing the effects of PBL, students were observed to do self-directed learning in PBL-style classes, and positive effects were observed in interests, motivation, attitude, class attendance, etc. (Vernon \& Blake, 1993). PBL began to be introduced in South Korea in the 1990s, and since then, related studies, such as comparisons with traditional lecture-type classes, have begun to appear (Lee, 2013).

Despite the positive results of studies of PBL in many aspects, it is not without difficulties in being applied to real classes. Vernon \& Hosokawa (1996) conducted a questionnaire survey about PBL classes with professors who had participated in PBL classes and with professors who had not. The results suggested that PBL classes can have a positive effect on creating students' interests and motivation, reasoning abilities, clinical preparation, and self-directed learning, but it might not improve class efficiency, acquisition of basic scientific knowledge, or hours spent. Limitations of the class hours, the discomfort of teachers and students unfamiliar with the PBL approach, etc., are obstacles in conducting PBL classes (Torp \& Sage, 2002).

PBL is characterized by the problems presented to students. Problems should not have a fixed answer and should not be ill-structured and complex situations. Learners need to be able to collect information from a variety of sources, conduct discussions among themselves, and prepare presentations on solutions. Though they are not sure of finding correct answers while preparing presentations, they can experience the process of exploring best decision-making by means of these activities (Stepien \& Gallagher, 1993). Professors participate in the discussions, serve as mentors and guides (Barrows, 1996), facilitate learning, and perform the evaluation. The issues that are covered in PBL approximate real-world situations, necessitating an integrated approach to solving them (Delisle, 1997). The effects of PBL on nursing students are more positive than traditional lectures in Korea (Choi, Lindquist, and Song, 2014). Critical thinking skills and overall metacognitive awareness scores increased significantly after using PBL (Gholami et al., 2016).

While although some studies have stated that PBL has positive effects on problem-solving abilities, self-directed learning skills, participation improvement, IT-related processes, analytical skills, learning ability, communication skills, etc. (Shin \& You, 2014), there are also other studies showing different results (Hung, 2009). Hung was concerned about excessive application of PBL without sufficient consideration of theoretical concepts (Hung, 2011). He showed that the hybrid class methods combining traditional methods and PBL can be applied easily to students unfamiliar with PBL.

Barrows \& Myers (1993) suggested a process of five steps to design PBL classes: Class progression, Presentation problems, Stages after problems, Presentation, Conclusion, and Post-solution issues. They designed classes to proceed in a hybrid format combining regular teaching curricula and PBL. The hybrid approach refers to the concurrent adoption of both the traditional process of knowledge delivery through lectures by professors and the process of solving problems by students themselves.

It is not easy to develop well-structured problems for PBL, and there are not enough classes to which PBL can be applied. Classes designed in a hybrid approach are not yet familiar enough to both learners and instructors for the complete conversion of existing class methods to PBL. Professors asked learners to investigate either enterprise cases or solutions using information technologies. Students had to investigate the information needed for job opportunities. Professors provided the necessary knowledge in 
the curriculum by traditional methods like lecturing. The companies investigated were ones that learners were willing to work for, and learners were allowed to choose the companies themselves.

The advantage of a hybrid approach was to make it possible to deliver, test, and objectively grade the necessary knowledge required by the regular curricula of the schools, but at the same time to make efforts for solving problems and to prepare for the presentation of the results.

\section{Methods \\ Study Design and Objects}

This study elucidates how a hybrid class applying PBL affected the career decision-making selfefficacy of women's university students. Before starting the study, we selected, as a control group, students at B University who were demographically similar to the A university students; all were taking IT- related courses. The curriculum that the students of A university would take was a 'Software Engineering' course, which was designed as a hybrid-style class. The curriculum that the students at B university would take included 'ERP', 'Management and Computers', and 'Office Automation (word processor)' courses; it was confirmed that the courses were administered in a computer lab. To verify the existence of a significant difference in career decision-making self-efficacy between the experimental group and the control group, we applied a nonequivalent control-group pretest-posttest design using pretests and posttests, as shown in Table 2.

$<$ Table 2> Pretests and posttests of the experimental group and control group

\begin{tabular}{|l|l|l|l|}
\hline & Pretests & $\begin{array}{l}\text { Applying Problem- } \\
\text { Based Learning }\end{array}$ & Posttests \\
\hline $\begin{array}{l}\text { A Women's University } \\
\text { (experimental group) }\end{array}$ & $\begin{array}{l}\text { Career decision-making } \\
\text { self-efficacy tests }\end{array}$ & O & $\begin{array}{l}\text { Career decision-making self- } \\
\text { efficacy tests }\end{array}$ \\
\hline $\begin{array}{l}\text { B Women's University } \\
\text { (comparison group) }\end{array}$ & $\begin{array}{l}\text { Career decision-making } \\
\text { self-efficacy tests }\end{array}$ & $\begin{array}{l}\text { Career decision-making self- } \\
\text { efficacy tests }\end{array}$ \\
\hline
\end{tabular}

\section{Tools}

This study used a Career Decision-Making Self-Efficacy Scale as a tool for measuring the confidence level of the students in career decision-making. Taylor \& Betz (1983) developed a Career Decision-Making SelfEfficacy Scale that could measure the confidence of individuals in their ability to successfully complete the tasks needed for deciding on their careers in general. This study used the revised version of Lee's adjusted 'The Short Form of Career Decision-Making Self-Efficacy Scale' applied by Taylor \& Betz (1983) themselves to the situation of South Korea (Lee, 2001). As shown in Table 3, the scale consisted of 5 subfactors (career information, setting goals, planning, solving problems, self-assessment) and a total of 25 items.

\begin{tabular}{|l|l|c|}
\hline \multicolumn{2}{|c|}{ <Table 3> Career Decision-Making Self-Efficacy Scale } & $\begin{array}{l}\text { Number of } \\
\text { questions }\end{array}$ \\
\hline $\begin{array}{l}\text { Career } \\
\text { information }\end{array}$ & $\begin{array}{l}\text { Details } \\
\text { and explore conditions required by the career specifically }\end{array}$ & 5 \\
\hline Setting goals & $\begin{array}{l}\text { The confidence that they can decide on their academic and career path } \\
\text { with confidence and no regret }\end{array}$ & 5 \\
\hline Planning & $\begin{array}{l}\text { The belief that they can plan and do the plan on the higher education or } \\
\text { career pathways. }\end{array}$ & 5 \\
\hline $\begin{array}{l}\text { Solving } \\
\text { problems }\end{array}$ & $\begin{array}{l}\text { The will that they will be able to cope with obstacles by themselves when } \\
\text { facing obstacles on the course. }\end{array}$ & 5 \\
\hline Self-assessment & $\begin{array}{l}\text { The confidence that they can clearly assess their abilities, values, desires } \\
\text { and choose their careers that suit them }\end{array}$ & 5 \\
\hline
\end{tabular}

\section{Data Collection and Analysis Methods}

This study was conducted for a total of 16 weeks on the students of A Women' University (the experimental group; PBL applied) and the students of B Women' University (the comparison group; PBL 
not applied). To conduct PBL class with both lectures and computer labs, each team of 2 or 3 persons performed assignments for solving problems. The students in the comparison group totaled 109, divided into 4 classes, where the teaching method consisted of general lectures and practices. To test career decision-making self-efficacy on the students at the two universities during the same period, the pretests and the posttests were used the same questionnaire

First, the study examined the demographic characteristics of the students and verified their homogeneity by using frequency and statistical analysis. Second, the study carried out an exploratory factor analysis and Cronbach's Alpha values to confirm the validity and reliability of the measuring instruments for career decision-making self-efficacy. Third, the study analyzed pre-post differences of the experimental group and of the control group for hypothesis testing. The analysis used a paired sample $t$ test, which examined whether there was a mean difference between the experimental group and the comparison group in the pre-post point differences about career information, setting goals, planning, solving problems, and self-assessment.

\section{Evaluation}

\section{Homogeneity of Study Objects}

Both the experimental group and the control group were derived from women's university students in South Korea. Ages ranged from 19 to 24; grades consisted of 2nd grade and 3rd grade (Table 4). Students took courses from an IT-related curriculum (Software Engineering, ERP, Management and Computers, Office Automation, etc.); classes were conducted in the classrooms where computer training facilities (personal computer units and a desk for the computers, beam projectors, lab software installation, etc.) were offered.

Table 4. Comparison of homogeneity between the experimental group and the control group

\begin{tabular}{|l|l|l|l|l|l|l|}
\hline \multirow{2}{*}{ Variables } & Experimental group (A) & Control group (B) & \multicolumn{2}{l|}{ Total } \\
\cline { 2 - 7 } & Mean & $\begin{array}{l}\text { Standard } \\
\text { Deviation }\end{array}$ & Mean & $\begin{array}{l}\text { Standard } \\
\text { Deviation }\end{array}$ & Mean & $\begin{array}{l}\text { Standard } \\
\text { Deviation }\end{array}$ \\
\hline Age & 20.91 & 0.97 & 20.40 & 0.94 & 20.64 & 0.99 \\
\hline Grades & 3.00 & 0.00 & 2.68 & 0.47 & 2.83 & 0.38 \\
\hline
\end{tabular}

\section{Validity and Reliability Analysis}

For the criterion for the reliability of the details in the questions about problem-solving abilities used in this study, the coefficient of Cronbach's Alpha was set to a value greater than 0.7, given that, if the alpha coefficient is above 0.7 in the analysis level of the general organizational units, the reliability of the measurement is known to have no problems (Nunnally, 1978). For the alpha coefficient of career information, setting goals, planning, solving problems, and self-assessment as the specific measurement items of career decision-making self-efficacy used in this study, pre-education values and post-education values were shown as in Table 5. There exists confidence between the measurement items, which are aggregated into factors, though some do not meet the criteria.

Principal component analysis and Varimax methods of orthogonal rotation were used for factor analysis. In this study, loading factors more than 0.3 were considered to meet goodness of fit, and some measured parameters below 0.3 have been removed.

Table 5. Validity and Reliability Analysis

\begin{tabular}{|c|c|c|c|c|c|c|c|c|c|c|}
\hline \multirow{3}{*}{ Factors } & \multirow{3}{*}{$\begin{array}{l}\text { Measurement } \\
\text { Variables }\end{array}$} & \multicolumn{4}{|c|}{ Loading Factor } & \multicolumn{4}{|c|}{ Cronbach's Alpha } & \multirow{3}{*}{ Remarks } \\
\hline & & \multicolumn{2}{|c|}{ Experiment } & \multicolumn{2}{|c|}{ Control } & \multicolumn{2}{|c|}{ Experiment } & \multicolumn{2}{|c|}{ Control } & \\
\hline & & Pre & Post & Pre & Post & Pre & Post & Pre & Post & \\
\hline \multirow{4}{*}{$\begin{array}{l}\text { Career } \\
\text { informatio } \\
\mathrm{n} \\
\text { (factor } 1 \text { ) }\end{array}$} & $\begin{array}{l}\text { Information on } \\
\text { career of interests }\end{array}$ & .415 & .689 & .684 & .591 & \multirow{4}{*}{.704} & \multirow{4}{*}{.803} & \multirow{4}{*}{.683} & \multirow{4}{*}{.790} & \multirow{4}{*}{$\begin{array}{l}\text { Removed } 1 \\
\text { variable } \\
\text { (information } \\
\text { on graduate } \\
\text { school) }\end{array}$} \\
\hline & $\begin{array}{l}\text { Employment } \\
\text { tendency }\end{array}$ & .682 & .755 & .648 & .511 & & & & & \\
\hline & Salary & .687 & .746 & .468 & .609 & & & & & \\
\hline & $\begin{array}{l}\text { Personal networks } \\
\text { in interested areas }\end{array}$ & .699 & .669 & .320 & .837 & & & & & \\
\hline Setting & Majors & .520 & .594 & .574 & .409 & .834 & .791 & .809 & .885 & \\
\hline
\end{tabular}




\begin{tabular}{|c|c|c|c|c|c|c|c|c|c|c|}
\hline \multirow{4}{*}{$\begin{array}{l}\text { goals } \\
\text { (factor 2) }\end{array}$} & Occupation & .702 & .627 & .673 & .792 & & & & & \\
\hline & Lifestyle & .450 & .444 & .694 & .737 & & & & & \\
\hline & No regret & .680 & .442 & .514 & .535 & & & & & \\
\hline & Selectable & .490 & .707 & .726 & .753 & & & & & \\
\hline \multirow{3}{*}{$\begin{array}{l}\text { Planning } \\
\text { (factor 3) }\end{array}$} & Resume & .814 & .836 & .705 & .814 & \multirow{3}{*}{699} & \multirow{3}{*}{.750} & \multirow{3}{*}{.771} & \multirow{3}{*}{.841} & \multirow{3}{*}{$\begin{array}{l}\text { Removed } 2 \\
\text { variables } \\
\text { (5 years plan) } \\
\text { (choosing } \\
\text { graduate } \\
\text { school) }\end{array}$} \\
\hline & $\begin{array}{l}\text { Company suited } \\
\text { the aptitude }\end{array}$ & .380 & .338 & .518 & .332 & & & & & \\
\hline & $\begin{array}{l}\text { Employment } \\
\text { procedure }\end{array}$ & .804 & .765 & .756 & .636 & & & & & \\
\hline \multirow{3}{*}{$\begin{array}{l}\text { Solving } \\
\text { problems } \\
\text { (factor 4) }\end{array}$} & $\begin{array}{l}\text { Changing the } \\
\text { choice }\end{array}$ & .787 & .842 & .737 & .711 & \multirow{3}{*}{.756} & \multirow{3}{*}{.799} & \multirow{3}{*}{.741} & \multirow{3}{*}{.780} & \multirow{3}{*}{$\begin{array}{l}\text { Removed } 2 \\
\text { variables } \\
\text { (changing } \\
\text { graduate } \\
\text { school) } \\
\text { (overcoming } \\
\text { obstacles) }\end{array}$} \\
\hline & $\begin{array}{l}\text { Adjusting the } \\
\text { career path }\end{array}$ & .769 & .824 & .753 & .809 & & & & & \\
\hline & $\begin{array}{l}\text { Preparing } \\
\text { alternatives }\end{array}$ & .827 & .821 & .616 & .779 & & & & & \\
\hline \multirow{5}{*}{$\begin{array}{l}\text { Self- } \\
\text { assessment } \\
\text { (factor 5) }\end{array}$} & Evaluating abilities & .778 & .769 & .700 & .399 & \multirow{5}{*}{.815} & \multirow{5}{*}{.872} & \multirow{5}{*}{.870} & \multirow{5}{*}{.849} & \\
\hline & Ideal occupation & .424 & .809 & .812 & .660 & & & & & \\
\hline & Value priority & .798 & .544 & .763 & .769 & & & & & \\
\hline & $\begin{array}{l}\text { Sacrifice } \\
\text { selection }\end{array}$ & .672 & .507 & .757 & .622 & & & & & \\
\hline & Lifestyle & .721 & .618 & .758 & .549 & & & & & \\
\hline
\end{tabular}

The removed measurement variables were the ones related to pursuing an academic career path directly upon graduation or going to graduate school; the variables were not meaningful to most of the students, who wanted to get jobs. In addition, the questionnaire variables were not appropriate in terms of the standard of the loading factors. The measurement item of '5-year plan' was also removed from planning; it was the question about whether students were able to plan out the coming 5 years. The item of 'overcoming obstacles' was removed from the factors of solving problems because it did not meet the standard of the loading factor; it was the question about whether students continued to work toward goals in difficult situations.

\subsection{Hypothesis Testing}

The results of the comparison of the details between the PBL-applied experimental group and the control group were as shown in Table 6.

First, although the hypothesis that students who participated in PBL classes could improve their confidence about their ability to search for career information showed a significant difference in the experimental group $(t=-2.16, p=0.033)$, the hypothesis did not show any significance in the control group $(t=1.39, p=0.168)$. Therefore, the hypothesis was supported. Second, for the hypothesis about confidence in setting goals, the experimental group showed a significant difference between before PBLapplication and after PBL-application $(t=-2.20, p=0.030)$; the control group showed the opposite result $(t$ $=2.08, \mathrm{p}=0.040)$. In other words, in the tests conducted at the beginning and the end of the semester, the control group showed less confidence in setting goals $(p<0.05)$ at the end of the semester than they had at the beginning. This result suggests that the confidence in setting goals was decreasing with time. Third, for the belief about planning and doing, the experimental group showed a significant difference $(t=-2.36$, $p=0.020$ ); the control group showed an insignificant change. Fourth, the conviction that students could solve problems by themselves showed a slightly improved value in the mean, but both the experimental group and the control group showed insignificant change. Fifth, for the confidence that students could evaluate the occupations that suited themselves, the experimental group showed a significant difference even though it was not conspicuous $(t=-1.97, p=0.052)$, but the control group showed insignificant change. 
$<$ Table 6> Comparison between pretest and posttest by the t-test

\begin{tabular}{|c|c|c|c|c|c|c|c|c|c|}
\hline \multirow[b]{2}{*}{ Factors } & \multirow[b]{2}{*}{$\begin{array}{l}\text { Group } \\
\text { classification }\end{array}$} & \multicolumn{2}{|l|}{ Pretest } & \multicolumn{2}{|c|}{ Posttest } & \multicolumn{2}{|c|}{ Difference analysis } & \multirow[b]{2}{*}{$t$} & \multirow[b]{2}{*}{$\mathrm{p}$} \\
\hline & & Mean & $\begin{array}{l}\text { Standard } \\
\text { Deviation }\end{array}$ & Mean & $\begin{array}{l}\text { Standard } \\
\text { Deviation }\end{array}$ & Mean & $\begin{array}{l}\text { Standard } \\
\text { Deviatio } \\
\mathrm{n} \\
\end{array}$ & & \\
\hline \multirow{2}{*}{$\begin{array}{l}\text { Career } \\
\text { information }\end{array}$} & Experiment & 4.15 & 0.98 & 4.47 & 1.09 & -0.32 & -0.11 & -2.16 & 0.033 \\
\hline & Control & 4.45 & 0.93 & 4.27 & 0.99 & 0.18 & -0.06 & 1.39 & 0.168 \\
\hline \multirow{2}{*}{ Setting goals } & Experiment & 4.55 & 1.04 & 4.85 & 1.01 & -0.30 & 0.03 & -2.20 & 0.030 \\
\hline & Control & 4.85 & 0.94 & 4.59 & 4.59 & 0.26 & -3.65 & 2.08 & 0.040 \\
\hline \multirow{2}{*}{ Planning } & Experiment & 3.89 & 0.97 & 4.21 & 1.06 & -0.32 & -0.09 & -2.36 & 0.020 \\
\hline & Control & 4.35 & 0.95 & 4.24 & 1.00 & 0.11 & -0.05 & 0.92 & 0.358 \\
\hline \multirow{2}{*}{$\begin{array}{l}\text { Solving } \\
\text { problems }\end{array}$} & Experiment & 4.51 & 1.08 & 4.87 & 0.87 & -0.36 & 0.21 & -0.29 & 0.839 \\
\hline & Control & 4.57 & 0.95 & 4.61 & 0.95 & -0.04 & 0.00 & -0.28 & 0.781 \\
\hline \multirow{2}{*}{$\begin{array}{l}\text { Self- } \\
\text { assessment }\end{array}$} & Experiment & 4.87 & 0.87 & 5.13 & 0.91 & -0.26 & -0.04 & -1.97 & 0.052 \\
\hline & Control & 4.93 & 0.95 & 4.78 & 0.91 & 0.15 & 0.04 & 1.32 & 0.189 \\
\hline
\end{tabular}

The results of this study indicated that students who took PBL-applied classes showed a significant difference in the mean value of the abilities before education versus after education in terms of the factors of career information, setting goals, planning, and self-assessment more than did students who took general-lecture-centric classes. However, the study did not prove that self-conviction would improve in the factor of solving problems.

\section{Concluding Remarks}

This study designed and carried out PBL-applied classes to examine the effects of PBL on career decision-making self-efficacy of women's university students. It was shown that, after applying PBL, the students of the experimental group could improve their confidence in their ability to to find information on job opportunities and the career that they wanted, perhaps because the problems (or tasks) assigned to them during class hours were to investigate IT solutions that the companies where they would want to work were using as management tools; and in the process, the salary levels and the working conditions of the companies could be identified simultaneously.

Women's universities that want to increase the employment rate of university graduates need to actively consider using PBL in an IT-related Curriculum. Although every university has a variety of employment support programs in operation, the most important curricula and class methods are not changing that much. PBL can be an alternative for improving current ways of class operation and can be expected to enable students to take the initiative in their career decisions.

The results showed that the confidence with which students evaluated their abilities more clearly and selected an occupation to meet their expectations was improved through PBL. The most important element in their career choice may be to know what they are interested in and what they can do best. We suggest that PBL enables students to improve their confidence in self-assessment and to evaluate their abilities and values properly.

Will and confidence in solving problems are somewhat different from problem-solving abilities; this study measured both will and confidence, focusing on self-efficacy. If students do not face difficulties or obstacles in the process of solving problems, it is not easy to measure whether will and confidence in solving problems are improved or not. The self-efficacy of students differs from the abilities of students; so, it is necessary to develop a new PBL-applied class design in a way that enables students to improve their self-efficacy as well as their problem-solving abilities. The topic of whether PBL classes can improve problem-solving abilities requires additional studies in the future.

This study has a limitation in that it assumed that higher career decision-making self-efficacy would lead to higher employability. There is a need to empirically analyze whether students who obtained higher self-efficacy would have a higher employment rate upon graduation. Job mismatching is not an easy problem to solve, but a new study is needed to find out whether the higher career decisionmaking self-efficacy affects collaborative research in universities and companies. 


\section{References}

Bandura, A. (1977). Self-efficacy: Toward a unifying theory of behavioral change. Psychological Review, 84, pp. 191-215.

Barrows, S. B. (1996). Problem-based learning in medicine and beyond: A brief overview. New Directions for Teaching and Learning, 68, pp. 3-12.

Barrows, H. S. \& Myers, A. C. (1993). Problem-based learning in secondary schools. Unpublished monograph. Springfield, IL, Problem-based Learning Institute. Lanphier high school and Southern Illinois University Medical School.

Betz, N. E., Klein, K. L., \& Taylor, K. M. (1996). Evaluation of a Short Form of the Career Decision-Making SelfEfficacy Scale, Journal of Career Assessment, 4(1), pp. 47-57.

Choi, E., Lindquist, R., \& Song, Y. (2014). Effects of problem-based learning vs. traditional lecture on Korean nursing students' critical thinking, problem-solving, and self-directed learning. Nurse education today, 34(1), pp.52-56.

Delisle, R. (1997). How to use problem-based learning in the classroom, Association for Supervision and Curriculum Development, Alexnadria, VA.

Gholami, M., Moghadam, P. K., Mohammadipoor, F., Tarahi, M. J., Sak, M., Toulabi, T., \& Pour, A. H. H. (2016). Comparing the effects of problem-based learning and the traditional lecture method on critical thinking skills and metacognitive awareness in nursing students in a critical care nursing course. Nurse education today, 45 , pp.16-21.

Hackett, G. \& Betz, N. (1981). A self-efficacy approach to the career development of women, Journal of Vocational Behavior, 18(3), pp. 326-339.

Hung, W. (2009). The 9-step problem design process for problem-based learning: Application of the 3C3R model. Educational Research Review, 4(2), pp. 118-141.

Hung, W. (2011). Theory to Reality: A Few Issues in Implementing Problem-Based Learning. Education Technology Research $\mathcal{E}$ Development, 59, pp. 529-552.

Kim, Dong-chul., Kim, Jung-won. (2015). An ease-up solution of job mismatch for local young men. : With a case study of Kangwon National University LINC program. The Korean Journal of Human Resource Development Quarterly, 17(2), pp.215-239.

Lee, Jeong-Mee. (2013). The Effects of Problem-Based Learning on Self-Regulated Learning Ability in LIS Education: Based on Cognitive and Motivational Components. Journal of Korean Library and Information Science, 47(4), pp. 60-67.

Lee, Eun-Jin. (2001). Effects of career-planning group counseling for multi-potential university students. Dissertation. Yonsei University.

Lent, R. E., Brown, S. D. \& Hackett, G. (2002). Social Cognitive Career Theory in Career Choice and Development (fourth edition), Jossey-Bass, San Francisco.

Liu, Hsiang-Yin, Chen, J. (2014). Are There Long-Term Effects on Wages When Graduating in A Bad Economy in Taiwan? Asian Economic and Financial Review, 4(10), pp.1347-1362.

Luzzo, D. A. (1996). Exploring the relationship between the perception of occupational barriers and career development. Journal of Career Development, 22(4), pp. 239-248.

McArdle, S., Waters, L., Briscoe, J., \& Hall, D. (2007) Employability during unemployment: Adaptability, career identity and human and social capital, Journal of Vocational Behavior,71, pp. 247-264.

Nunnally, J. C. (1978). Psychometric method, McGraw-Hill, New York, 1978.

Restbog, S. L., Florentino, A., \& Garcia, P. (2010). The mediating roles of career self-efficacy and career decidedness in the relationship between contextual support and persistence, Journal of Vocational Behavior, 77(2), pp. 186-195.

Shin, S. \& You, D. (2014). Effects of Hybrid Style Problem-Based Learning in Food Service Entrepreneurship Subject Focusing on Problem Solving Skills, Journal of the Korea Contents Association, 14(6), pp. 453-365.

Stepien, W. \& Gallagher, S. (1993). Problem-based learning: As authentic as it gets. Educational Leadership, 50(7), pp. 2528.

Taylor, K. M. \& Betz, N. E. (1983). Applications of self-efficacy theory to the understanding and treatment of career indecision, Journal of Vocational Behavior, 22(1), pp. 63-81.

Torp, L. \& Sage, S. M. (2002). Problem as Possibilities: Problem Based Learning for K-16 Education (2nd Eds.) Association for Supervision and Curriculum Development.

Vernon, D. \& Blake, R. L. (1993). Does problem-based learning work? A meta-analysis of evaluative research, Academic medicine, 68(7), pp.550-563.

Vernon, D. \& Hosokawa, M. (1996). Faculty attitudes and opinions about problem-based learning, Academic Medicine, 71(11), pp. 233-238

Vinokur, A. D., Van Ryn, M., Gramlich, E. \& Price, R. (1991). Long-term follow-up and benefit-cost analysis of the Jobs Program: A preventive intervention for the unemployed. Journal of Applied Psychology, 76(2), pp.213-219. 